Kjersti Fløttum

Professor ved Institutt for fremmedspråk

Universitetet $i$ Bergen

Tonje J. Espeland*

Rådgiver ved Direktoratet for samfunnssikkerhet og beredskap

\title{
Norske klimanarrativer - hvor mange "fortellinger"? \\ En lingvistisk og diskursiv analyse av to norske stortingsmeldinger
}

\begin{abstract}
This article explores how climate change is framed in the Norwegian White Papers on Climate Policy and on the High North (2011-2012). Scientific as well as political representations of climate change influence individual attitudes and public opinion; thus, climate change communication has become increasingly salient in recent years. In line with this, a growing number of studies focusing on various linguistic and discursive matters of climate change communication have been published. The present paper aims at contributing to this field through an analysis based on a theoretical framework comprising approaches of narrative and polyphonic (multi-voiced) perspectives. Norway is a large oil and gas provider and the country also has a reputation as leading in environmental issues. These conflicting roles are reflected in the country's policies. The analysis uncovers competing "voices" in the two documents. These findings raise the question of what impact conflicting frames have on public opinion and behaviour.
\end{abstract}

\section{Sammendrag}

Denne artikkelen undersøker hvordan klimafenomenet presenteres $i$ to norske stortingsmeldinger: Norsk klimapolitikk og Nordområdene. Visjon og virkemidler (2011-2012). Vitenskapelige så vel som politiske fremstillinger av klimaendringer påvirker individuelle og kollektive holdninger og meninger. Klimakommunikasjon har i det siste tiåret derfor fått mye oppmerksomhet $i$ et voksende antall publikasjoner som studerer ulike språklige og diskursive sider av språkbruken om klima. Målet med denne artikkelen er å bidra til dette feltet gjennom en analyse basert på et teoretisk rammeverk som inkluderer narrative og polyfoniske (flerstemmige) perspektiver. Norge er en stor olje- og gassprodusent samtidig som landet er anerkjent som ledende $i$ miljøspørsmål. Disse ulike rollene reflekteres $i$ landets politikk. Resultatene av analysen avdekker konkurrerende "stemmer" $i$ de to dokumentene. Dette reiser spørsmålet om hvilken innvirkning motstridende klimaperspektiver har på folks meninger og adferd. 


\section{Innledning}

Klima og klimaendringer har i det siste tiåret utviklet seg til å bli et overordnet politisk tema med store utfordringer knyttet til kommunikasjon (Giddens 2009: 3; Hulme 2009: 25; Jones 2013: 3; Nerlich et al. 2010: 1). Det er derfor viktig å få en bedre forståelse av hvordan sentrale samfunnsaktører og politikere formidler klimaproblemene, og hvordan formidlingen påvirker meninger, holdninger og adferd (Nerlich et al. 2010). I denne artikkelen søker vi å analysere hvordan to stortingsmeldinger knyttet til klima er språklig og diskursivt konstruert: Norsk klimapolitikk (Meld. St. 21, 2011-2012; Klimameldingen) og Nordområdene. Visjon og virkemidler (Meld. St. 7, 2011-2012; Nordområdemeldingen). Stortingsmeldinger er politiske dokumenter som vanligvis publiseres for å presentere en regjerings politiske preferanser og kommende forslag til tiltak eller lovgivning på et bestemt område (se også Fløttum \& Gjerstad 2013b; Krzyżanowski 2013). Siden Norge er i en situasjon der landet må takle klimautfordringene samtidig som det arbeides for å videreutvikle petroleumsindustrien, ønsker vi her å undersøke i hvilken grad de to dokumentene bidrar til flerstemmige budskap i norsk klimapolitikk. Hovedmålet med analysene vi foretar her, er derfor å teste hypotesen om at norsk politisk diskurs om klima er preget av doble budskap.

I det siste tiåret er det gjennomført mye forskning på klimadiskurs innen ulike disipliner, som medie- og kommunikasjonsvitenskap, statsvitenskap, sosiologi, psykologi og etikk (Boykoff 2011; Carvalho 2005; Krosnick et al. 2006; Krzyżanowski 2013; Kurz et al. 2010; Leizerowitz 2006; Nisbet 2009; Norgaard 2006; Painter 2011; Ryghaug et al. 2011; Weber 2006). Flere av disse tar for seg tekstperspektiver, for eksempel via «framing»-analyse (Entman 1993; Nisbet 2009) og innholdsanalyse (Eide et al. 2010; Trumbo 1996).

Hulme (2009) hevder at klima er et særlig tøyelig begrep. Han viser at det har utviklet seg fra å gjelde i all hovedsak et fysisk fenomen til samtidig å omfatte politiske og sosiale fenomener. Vi mennesker tolker og gjentolker gjennom våre kulturelle, sosiale, politiske og etiske praksiser hva klimaendringer betyr: "Climate change can be framed, can be moulded, in many different ways. Sometimes these frames complement each other, yet often they appear to conflict." (Hulme 2009: 28). I et slikt perspektiv blir lingvistiske og diskursive analyser særlig relevante (se for eksempel Fløttum og Dahl 2011, 2012; Fløttum og Gjerstad 2013a, 2013b; Koteyko 2012; Koteyko et al. 2010; for et perspektiv innenfor retningen «critical discourse analysis», se Krzyżanowski 2013; Wodak 2013). I den analysen vi gjennomfører i denne artikkelen, ønsker vi å belyse språklige virkemidler som er benyttet i to ulike stortingsmeldinger, samt å avdekke eventuelle motsetningsforhold innad i denne diskursen. Resultatet av analysen viser en flerstemmig klimadiskurs som i hovedsak preges av to perspektiver. Ett perspektiv peker på utfordringene ved klimaendringene og et annet på mulighetene til utvikling av petroleumsindustrien.

Vår teksttilnærming til de to stortingsmeldingene er narrativ. Narrativ-begrepet har tidligere blitt brukt som innfallsvinkel i statsvitenskapelige analyser av klimaspørmålet (Jones og McBeth 2010). Jones (2013) undersøker hvordan narrative strukturer kan påvirke publikums oppfatning av risiko og politiske preferanser knyttet til klima. Han understreker at man for å forstå folks oppfatninger bør relatere analysene til overordnete klimanarrativer som 
finnes i den aktuelle konteksten. I et lingvistisk perspektiv har Fløttum (2013), Fløttum og Dahl (2012) og Fløttum og Gjerstad (2013a, b) undersøkt relevansen til det klassiske narrativbegrepet («fortellingen») i analyser av klimakommunikasjon og videre utvidet den narrative analysen med et polyfonisk perspektiv, inspirert av ScaPoLine-teorien om lingvistisk polyfoni (Nølke et al. 2004; se også Dahl \& Fløttum 2014). Fløttum \& Gjerstad (2013b) anvender en kombinert lingvistisk og diskursiv tilnærming i sin studie av et sørafrikansk White Paper om klimaendringer. De analyserer hvordan dette dokumentet konseptualiserer klimaspørsmålet som en narrativ fremstilling, hvor både innholds- og kontekstperspektiver er inkludert. I denne artikkelen vil vi følge en liknende tilnærming i analysen av de to stortingsmeldingene - en analyse i tre trinn: Først blir det narrative perspektivet anvendt i en makrostrukturell forståelse av klimadiskursen (teksten som helhet). Deretter integrerer vi kontekstuelle faktorer for å nå en dypere forståelse av de «fortellingene» som blir presentert. Til slutt blir manifeste polyfoniske uttrykk identifisert på et mikro- eller ord-/setningsnivå; dette er ulike uttrykk som tilfører språklig kompleksitet til den kompleksiteten som allerede karakteriserer klimafenomenet.

\section{Metodologisk og teoretisk ramme}

\subsection{Metodologisk tilncerming}

Norsk politikk preges som allerede nevnt av en balansegang mellom klimahåndtering og utvikling av olje- og gassindustrien. Hovedmålet med de analysene vi foretar her, er derfor å teste hypotesen om at norsk politisk diskurs om klima er preget av doble budskap. De to stortingsmeldingene ble valgt ut fra en vurdering av klimarelevans i et utvalg nyere offentlige dokumenter. Dokumentene ble også valgt med tanke på å avdekke motsetninger i regjeringens klimadiskurs og å få frem hvilke språklige virkemidler som anvendes for å presentere dem. Vi søker å vise at det er fruktbart å kombinere en tilnærming på både makro- og mikronivå - det narrative og det polyfoniske. $\mathrm{Vi}$ hevder at en narrativ analyse som favner om ulike komponenter og aktører, gir en mer fullstendig forståelse av den klimadiskursen som analyseres her. Det er mange synspunkter og ofte motstridende interesser i klimadebatten, og det blir viktig å identifisere hvem som sier hva. For videre å gripe tak i de enkelte budskapene på mikronivå mener vi det er fruktbart å ta i betraktning språklige og polyfoniske virkemidler som er uttrykk for både eksplisitte og implisitte (skjulte) stemmer i diskursen.

Vår lingvistisk-diskursive tilnærming er i hovedsak kvalitativ og er basert på en overordnet narrativ innholdsanalyse gjennom nærlesning av de to dokumentene. For å sette denne inn i en bredere sammenheng vurderer vi relevansen av ulike kontekstuelle faktorer. De kontekstuelle faktorene er hentet fra norsk offentlig klimadebatt slik den ofte er gjenspeilt blant annet i mediene. FNs klimapanels rapporter og tidligere forskning har også vært viktige for å tilføre analysen relevante kontekstuelle rammer (se for eksempel Andresen et al. 2002; Eide et al. 2010; Ryghaug et al. 2011). Det empiriske materialet ble innhentet gjennom nærlesing av de to stortingsmeldingene med antagelsen om flerstemminghet lagt til grunn. Hovedvekten ble lagt på å identifisere den narrative helheten i de to meldingene, eventuelle 
motsetningsforhold i budskapet både innad i en melding og mellom de to meldingene, og på å velge ut sitater for den polyfoniske analysen basert på språklige virkemidler beskrevet i ScaPoLine-teorien. I noen tilfeller gjennomførte vi enkle kvantitative undersøkelser til støtte for den kvalitative hovedtilnærmingen.

\subsection{Klimanarrativer}

Tekster om klima kan etter vår oppfatning betraktes som klimanarrativer, selv om de kommer i mange ulike former og sjangre (Fløttum 2013: 279). En klimanarrativ er tekst eller tale som presenterer klimaendringer som en type komplikasjon, med implisitte eller eksplisitte anbefalinger eller forslag til tiltak og handling for å oppnå bestemte effekter eller løsninger (ibid.).

Med utgangspunkt i Jean-Michel Adams forskning om narrativer (Adam 1985, 2008) er fem hovedkomponenter i narrativstrukturen satt opp (Fløttum 2013: 280): 1) initialsituasjon, 2) komplikasjon, 3) reaksjon, 4) løsning og 5) finalsituasjon. Komponentene 2), 3) og 4) utgjør kjernen, og komplikasjonen er obligatorisk. I tillegg kan også en moral eller en evaluering være tilføyd. Uten å gå videre inn i en diskusjon om denne strukturen (se Fløttum 2013) illustrerer vi den her med et konstruert, men realistisk eksempel:

(1)

1. Initialsituasjon: $\mathrm{CO}_{2}$-nivået $\mathrm{i}$ atmosfæren var i lang tid stabilt med naturlige variasjoner.

2. Komplikasjon: Siden 1990 har $\mathrm{CO}_{2}$-utslippene økt dramatisk og har forårsaket alvorlige klimaendringer.

3. Reaksjon: FN organiserer internasjonale toppmøter (COP) for å diskutere tiltak mot klimautfordringene.

4. Løsning: Landene som deltar i forhandlingene, har ikke nådd frem til en bindende avtale om tiltak som kan gjennomføres.

5. Finalsituasjon: Klimaendringene utgjør en alvorlig trussel for jorden og for fremtidige generasjoner, og de som har bidratt minst til problemene, er også de som er mest sårbare for konsekvensene.

Dette er bare ett eksempel på hvordan man kan tenke seg at en klimanarrativ kan realiseres. Når det gjelder det ovenstående eksemplet, kunne en annen fremstilling ha gjort komplikasjonen til initialsituasjon, og deler av finalsituasjonen kunne ha utgjort narrativens moral («de som har bidratt minst ... er også de som er mest sårbare ...»).

Et viktig poeng i den overordnete beskrivelsen av narrativer er at den fremstilte historien inneholder en intrige (et plott), det vil si et problem eller en komplikasjon som følges av en serie hendelser eller handlinger som man utfører for å oppnå en effekt (Fløttum 2013: 281). Et annet trekk er rekkefølgen av hendelser i tid. Et tredje og viktig trekk er tilstedeværelsen av aktører/deltakere som får eller inntar roller som «helt», «skurk» og «offer». 
De to stortingsmeldingene som skal analyseres her, er ikke bygd opp med en kapittelstruktur som direkte gjenspeiler komponentene i den narrative strukturen, men spor av komponentene og eksplisitte og implisitte aktører er identifiserbare på ulike måter gjennom dokumentene.

\subsection{ScaPoLine-teorien}

Mens den narrative strukturen tjener som en ramme for analyse av tekster i sin helhet (makronivået), anvender vi ScaPoLine-teorien til den polyfoniske analysen på ord- eller setningsnivå. ScaPoLine, en forkortelse for «La Théorie scandinave de polyphonie linguistique», er en teori om lingvistisk polyfoni (Nølke et al. 2004). I en forenklet fremstilling kan vi si at denne tilnærmingen er basert på en oppfatning av språk som dialogisk; den er et alternativ til den etablerte ideen om det unike talende subjekt. Hovedprinsippet er at det $i$ en enkeltstående ytring kan finnes flere stemmer eller synspunkter i tillegg til talerens eller forfatterens egen stemme. Teorien kan anvendes for å klargjøre komplekse flerstemmige sekvenser med ulike synspunkter som dels er eksplisitt uttrykt for eksempel i sitater eller gjengitt tale, dels implisitt signalisert gjennom ulike markører som adverb, konnektorer eller pronomen (mer om teorien i Fløttum 2005; Fløttum et al. 2006; Fløttum \& Dahl 2011; Fløttum \& Stenvoll 2009).

De ulike språklige konstruksjonene nedenfor (2- ) er alle eksempler på implisitt polyfoni, uten angivelse av eksplisitt kilde for de ulike synspunkter som er sammenfiltret på forskjellige vis. De representerer subtile måter å argumentere og bringe inn ulike synspunkter på uten å måtte oppgi de underliggende kildene:

Polemisk nekting gjennom markøren ikke har en avvisende funksjon, som her:

(2) Klimaendringene er ikke menneskeskapte.

Vi har å gjøre med to synspunkter (sp): et implisitt som sier 'klimaendringene er menneskeskapte' (sp1), og et annet som karakteriserer det første som ugyldig gjennom ikke (sp2). Taleren er ansvarlig for sp2 (avvisningen), men konstruksjonen sier intet om kilden til sp1. Denne kilden kan bli identifisert ved at man trekker inn konteksten.

Den kontrastive konnektoren men i sin innrømmende betydning bidrar til en konstruksjon hvor to sp settes opp, som to argumenter som peker i retning av ulike, implisitte konklusjoner, i en konstruksjon $p$ men $q$ :

(3) Klimaendringene er et komplekst globalt fenomen, men konsekvensene blir erfart lokalt.

Taleren innrømmer enighet med innholdet i setningen som står foran men $(p)$, mens innholdet i setningen som følger etter men $(q)$, utgjør det synspunktet som taleren vurderer som det viktigste her og nå (se også Fløttum \& Stenvoll 2009). 
Typiske trekk i klimadiskursen er konstruksjoner og ordvalg som gjelder usikkerhet, nødvendighet/plikt og evaluering. Disse kan være polyfoniske og karakteriseres som synspunkter som legges over en underliggende «nøytral» ytring. Nedenfor følger noen eksempler.

Epistemiske uttrykk angir (u)sikkerhet eller (u)sannsynlighet og realiseres gjennom virkemidler som modale hjelpeverb (kan, kunne) brukt med epistemisk betydning, men også gjennom en rekke adverb og konstruksjoner som det synes, det er mulig, det er sannsynlig. Det er en klar forskjell mellom «Havnivået vil stige med inntil $80 \mathrm{~cm}$ i løpet av de neste 100 årene.» og «Havnivået kan stige med inntil $80 \mathrm{~cm}$ i løpet av de neste 100 årene.»:

Deontiske uttrykk angir nødvendighet og er for eksempel verb som må, måtte, bør, burde og konstruksjoner som det er nødvendig å/at .... I ytringen

(4) Tilpasningstiltak for klimaendringene må gjøres innen to år.

er en klar nødvendighet uttrykt, hvor må også indikerer et underliggende synspunkt som sier at det finnes aktører som er i stand til å gjøre det som er uttrykt.

Presupposisjoner er polyfoniske $\mathrm{i}$ den forstand at de presenterer underliggende innhold som tas for gitt og dermed betraktes som akseptert av alle (Kerbat-Orecchioni 2002), som i ytringen

(5) Norge vil fortsette å være ledende i klimaforhandlingene.

hvor verbet fortsette impliserer at Norge allerede er «ledende i klimaforhandlingene». Dette er en måte å konstruere aksept på som kan være retorisk effektiv (Fløttum \& Gjerstad 2013b).

Alle disse virkemidlene bringer implisitt inn andre synspunkter enn det taleren fremsetter her og nå - synspunkter som kan «lekes» med på ulikt vis, gjennom avvisning, innrømmelse, nøling, påtvinging - uten at taleren trenger å gjøre eksplisitt hvem eller hva hun eller han fører en «dialog» med.

Det kan innvendes at denne teorien om lingvistisk polyfoni ikke er den eneste som kan gjøre rede for de språklige virkemidlene en analyse trenger å identifisere. Men vi mener den er et velegnet instrument for å angripe den semantiske kompleksiteten som er innebygd i flerstemmighet. I tillegg gjør teorien det mulig å bygge bro fra det semantisk mikrolingvistiske til det makrolingvistiske eller diskursive analysenivået (Fløttum \& Gjerstad 2013a; Dahl \& Fløttum 2014). Et like viktig argument kan være at teorien inneholder et helhetlig begrepsapparat som tillater enhetlige analyser av en rekke til dels svært forskjellige språklige fenomener som man ellers ville ha måttet beskrive og forklare med ulike og ikke allid lett kombinerbare teorier (fenomener som blant annet gjengitt tale, pronomen, modale hjelpeverb, konnektorer, adverb, nektingskonstruksjoner, presupposisjon). 


\section{Analyse av to norske stortingsmeldinger}

\subsection{Stortingsmelding $n r .21$ (2011-2012) Norsk klimapolitikk}

\section{Narrativ analyse:}

Vår tolkning av innholdet i Stortingsmelding nr. 21 (heretter: Meld. St. 21; Klimameldingen) $i$ et narrativt perspektiv kan fremstilles slik:

Initialsituasjonen er presentert som den urettferdige fordelingen av verdens rikdom og ressurser. Klimaendringene, sammen med fattigdom og sult, er verdens største problemer. Utviklingspolitikk blir dermed en viktig del av klimapolitikken. Et hovedspørsmål blir hvordan forskjellen mellom industrialiserte land og land under utvikling kan løses gjennom en internasjonal og bindende klimaavtale om rettferdig fordelte utslippskutt, hvor prinsippet om «forurenser betaler» skal gjelde, samtidig med at de verste konsekvensene av klimaendringene kan dempes. Komplikasjonen er det faktum at klimaendringene nå er ett av de mest presserende problemene på den globale agendaen. Klimaendringene kan ha store negative virkninger på økosystemene og på folks liv og helse, i tillegg til alvorlige økonomiske konsekvenser. Internasjonale avtaler skal danne rammen for reduksjon av klimagassutslipp (Meld. St. 21: 199).

Det hendelsesforløpet som presenteres, svarer til reaksjonene på den trusselen som klimaendringene representerer, først og fremst $\mathrm{i}$ form av internasjonale forhandlinger for å nå frem til en global klimaavtale. Meldingen anerkjenner FNs rammeverk (UNFCCC, United Nations Framework Convention on Climate Change) som det sentrale i disse forhandlingene (Meld. St. 21: 47).

Når det gjelder fremtiden (finalsituasjonen), understreker man at det internasjonale samfunnet har forpliktet seg til en temperaturøkning som i gjennomsnitt ikke skal overstige to grader. Dette togradersmålet kan bare nås dersom en internasjonal avtale og strenge nasjonale politikker blir gjennomført. Meldingen foreslår flere reaksjoner på denne utfordringen.

(6) Norges mangeårige prioritering av klimapolitikk og vår samlede innsats både ute og hjemme, gir oss troverdighet som pådriver og brobygger i det internasjonale klimaarbeidet. Vår prioritering av klimapolitikk skal også bidra til å skape internasjonal enighet om en ambisiøs klimaavtale. (Meld. St. 21: 8)

Når vi tolker Stortingsmeldingen som en narrativ, ser vi følgende oppbygging i fortellingen: Først og fremst er det den norske regjeringen som forutsetter enighet om tiltak og oppnådde resultater, som illustrert i eksemplet ovenfor (6). Regjeringen gir slik seg selv rollen som «helt» (eller «velgjører») i sin egen fortelling. Når det gjelder andre roller, fremstilles industrialiserte land som «skurkene» (som da skulle gjelde for Norge også); BRIK-landene (Brasil, Russland, India, Kina) betraktes som kommende «skurker» ettersom de forventes å stå for størsteparten av utslippene frem til 2050. Samtidig blir disse tildelt en offerrolle sammen med land under utvikling. I et langsiktig perspektiv er alle ofre for klimaendringer, 
men på kort sikt er det utviklingsland med forholdsvis små utslipp og stor fattigdom som mest sannsynlig vil oppleve de negative konsekvensene av klimaendringene raskest og hardest.

\section{Politisk kontekst:}

Norge er en stor produsent av olje og gass på det globale markedet; dette er en kontekstuell faktor som krever en særlig oppmerksomhet. Petroleumsindustrien utgjør ryggraden i landets økonomi og har bidratt til stor økning i bruttonasjonalproduktet siden oljeutvinningen i Nordsjøen startet på 1970-tallet. Imidlertid dekker Norge sitt eget behov for elektrisitet fra fornybar vannkraft, og over 90 prosent av den produserte oljen og gassen blir eksportert (2008). Som én av verdens største oljeprodusenter er Norge et land med høye reduksjonskostnader («high-cost abatement»), det vil si et land som kan få vansker med å møte klimakravene og kan bli hardt rammet av et samfunn som etterspør mindre av petroleumsproduktene (Andresen, Kolshus and Torvanger 2002: 1).

I et slikt interessebasert perspektiv kunne man forvente at Norge ville være imot ethvert klimaregulerende regime, men slik er det ikke. Tvert imot har Norge tradisjonelt presset på for en internasjonal klimaavtale og er anerkjent som et land som prioriterer internasjonale miljøspørsmål og bistand høyt (ibid.: 1).

I Norge blir petroleumsindustrien pålagt en avgiftsøkning på 200 NOK per tonn karbonutslipp (Meld. St. 21: 11). Til tross for dette tiltaket sier meldingen også følgende:

(7) Nye anslag viser at utslippene fra norsk petroleumsvirksomhet i 2020 ligger an til å bli om lag 3 millioner tonn høyere enn lagt til grunn i den forrige klimameldingen, [...]. Utslippene per produsert enhet er imidlertid lavere på norsk sokkel enn i de fleste andre olje- og gassproduserende områdene i verden. (s. 10)

$\mathrm{Vi}$ ser to budskap her. For det første skal petroleumsindustrien pålegges en økning $\mathrm{i}$ karbonavgiften, men avgiften vil ikke være i stand til å hindre en økning i utslippene. For det andre vil sektoren slippe ut mer enn forventet i 2020. Likevel er utslippene lavere her enn i andre land. Denne fremstillingen, som implisitt sier at norsk petroleum er «renere» og «bedre» enn andre lands, inviterer til en etisk vurdering av politikken. Stortingsmeldingen legger gjennomgående vekt på det ansvar Norge har for miljø og bærekraft både hjemme og ute. Den tar imidlertid ikke opp de etiske implikasjonene som er knyttet til petroleumseksport (Meld. St. 21: 10).

Kontekstuelle forhold spiller en stor rolle også på det internasjonale planet. Stortingsmeldingen peker spesielt på to: usikkerhet og kompleksitet. Teksten understreker Norges engasjement $\mathrm{i}$ internasjonale forhandlinger som har til hensikt å nå togradersmålet, men innrømmer at dette kun er mulig dersom alle land gjennomfører tiltak for utslippskutt (Meld. St. 21: 7). Ifølge FNs klimapanel er det betydelig usikkerhet rundt temperaturmålsettingen og beregningen av hvor store klimagassutslipp som kan tillates. Stortingsmeldingen anerkjenner at jo lenger man tillater økning i utslipp etter 2015, jo mindre sannsynlig er det at verden vil 
lykkes i å nå togradersmålet (Meld. St. 21: 38-39). En internasjonal avtale fremheves som den eneste tilfredsstillende måten å takle klimaendringene på:

(8) Klimaproblemet kan bare løses gjennom bred internasjonal samhandling. Det meste av den konkrete politikken bestemmes likevel nasjonalt. Det er stor usikkerhet knyttet til når verden får på plass en tilstrekkelig ambisiøs, bred og juridisk bindende klimaavtale. (s. 9)

Vi observerer her at stortingsmeldingen konstruerer et nytt dobbelbudskap som understreker kompleksiteten i problematikken På den ene siden vil det være vanskelig å nå togradersmålet. Det kan bare nås gjennom betydelige utslippskutt, men det er usikkert hvor store utslipp som kan tillates. På den andre siden er det behov for handling nå. Klimaspørsmålet kan bare løses gjennom en internasjonal avtale, men det er usikkert om og når en slik avtale kan komme i stand. Sidestillingen av disse to budskapene fremhever den vitenskapelige usikkerheten rundt klimapolitiske tiltak så vel som begrensningen den påfører beslutningstakerne.

Vi ser altså at kontekstuelle faktorer som usikkerhet og kompleksitet spiller nøkkelroller i de fremtidsperspektivene som er presentert i meldingen. Det dreier seg her hovedsakelig om temperaturøkning og politiske tiltak (reaksjon) knyttet til disse. Meldingen gjør intet forsøk på å presentere ulike scenarier (finalsituasjon) som tar hensyn til ulike temperaturendringer eller klimatiltak.

Etter å ha studert stortingsmeldingen som en narrativ i et diskursivt perspektiv skal vi i det følgende se på mer språklige trekk i et polyfonisk perspektiv.

\section{Polyfonisk analyse:}

Når vi tar på de polyfoniske brillene, ser vi at meldingen i stor utstrekning støtter seg på stemmer fra internasjonale organisasjoner som IPCC (FNs klimapanel), OECD (Organisasjonen for økonomisk samarbeid og utvikling), IEA (Det internasjonale energibyrået) og World Resource Institute. Uttrykket «ifølge» fulgt av en referanse til en internasjonal organisasjon forekommer 25 ganger i meldingen. Her er et eksempel:

(9) Uten nye tiltak ventes de globale utslippene av klimagasser å øke med rundt 50 prosent fram mot 2050, ifølge Organisasjonen for økonomisk samarbeid og utvikling. (s. 39)

Bruken av uttrykket «ifølge» er en måte å referere eksplisitt til kilden for et formidlet argument på. Regjeringen støtter seg på anerkjente kilder (se Grundmann 2007), noe som gjør argumentet med referanse til et "argument by authority" (Nølke et al. 2004; Fløttum \& Gjerstad 2013a). Eksemplet ovenfor gir dessuten rom for to lesninger. Den første, som er eksplisitt, stadfester at uten klimatiltak vil utslippene øke, med en underliggende antakelse om at dette vil ha negative konsekvenser for mennesker og miljø. Den andre lesningen, implisitt, er at utslippsøkningen kan unngås dersom nye klimatiltak settes i verk (uttrykt gjennom preposisjonen «uten»). 
I utdraget nedenfor finner vi et eksempel på implisitt polyfoni i tilknytning til usikkerheten i de foreslåtte klimatiltakene:

(10) De foreslåtte tiltakene i denne meldingen innebærer en sterkere klimasatsing på flere områder. Det er ikke mulig på sikkert grunnlag å anslå effekten av denne satsingen i 2020. (s.

11)

Gjennom nektingen «ikke» avviser regjeringen (som den ansvarlige forfatter av meldingen) et synspunkt som sier at det er mulig å anslå effekten i 2020 av satsingen. I den konteksten vi kjenner i Norge, kan dette tolkes som en avvisning av synspunkter som går imot klimasatsing, fra motstandere som krever sikre anslag av tiltak før de eventuelt støtter dem.

Problemene og kompleksiteten i klimapolitikken kommer ofte til uttrykk, som i det følgende eksemplet:

(11) Mindre framgang i utvikling av klimavennlig teknologi, høyere kostnader ved klimatiltak innenlands, høyere innvandring og økonomisk vekst og større utslipp fra oljesektoren vil ha betydning for når klimamålene blir nådd. Men disse forholdene endrer likevel ikke behovet for å redusere de nasjonale utslippene. (s. 10)

Dette utdraget er et eksempel på en konstruksjon med den kontrastive og innrømmende konnektoren «men». Synspunktet i den første setningen er at mange faktorer kan bidra til å hindre at man når klimamålene. Det andre synspunktet, innledet av «men», understreker imidlertid at disse målene ikke dermed blir mindre viktige. Dette siste synspunktet, det viktigste her og nå, sikter mot argumentet om at reduksjon av utslipp er umulig fordi det er avhengig av så mange faktorer. I tillegg bidrar «likevel ikke» til kompleksiteten i utdraget.

Stortingsmeldingen presenterer en rekke tiltak som Norge burde gjennomføre for å ta nødvendig ansvar. Karbonprising er hjørnesteinen i denne politikken:

(12) Skal verden lykkes med å redusere utslippene i tråd med togradersmålet, må det etableres en internasjonal pris på utslipp av karbon. [...] Karbonprising vil være vårt viktigste virkemiddel i arbeidet mot de globale klimaendringene. (s. 8)

I dette utdraget ligger det et klart deontisk budskap om forpliktelse i ordvalget «må det etableres», men det underliggende synspunktet om at det finnes kapasitet i verden til å gjøre det, er ikke uttrykt (enn si hvilken grad av kapasitet som finnes). Igjen blir ansvar lagt til fremtiden og sagt å forutsette internasjonalt samarbeid. Den direkte relasjonen mellom norske klimatiltak og effekter er tilslørt. Samtidig som karbonprising vektlegges som et middel til å bekjempe klimaendringer, anerkjenner forfatterne med FNs klimapanels stemme (se 13 nedenfor) at det er usikkert hvor store utslipp som kan tillates om man skal nå målet:

(13) Ifølge FNs klimapanel er det betydelige usikkerheter forbundet med å oversette et temperaturmål til hva en kan tillate av globale utslipp av klimagasser. (s. 37) 
(14) EUs kvotesystem vil ikke alene være tilstrekkelig til at landene som er omfattet av systemet når sine klimamål. (s. 10)

Utsagnet i eksempel (14) vurderer likeledes EUs kvotesystem som ikke tilfredsstillende, idet synspunktet om etableringen av et slikt marked tilbakevises gjennom nektingen «ikke». Usikkerheten uttrykkes videre i eksempel (15) ved at etableringen av et globalt karbonmarked vurderes som «ikke sannsynlig dette tiåret», det vil si i nær fremtid. Usikkerheten fortsetter gjennom det epistemiske «kan være» i påfølgende setning:

(15) Etablering av et globalt CO2-marked eller en global CO2-avgift synes ikke sannsynlig dette tiåret. En mer realistisk vei kan være å kople nasjonale og regionale karbonmarkeder til hverandre over tid. (s. 15)

Gjennom disse eksemplene, som er gitt en forenklet polyfonisk analyse, ser vi klart at karbonprising kun er foreslått som en delløsning, med mye usikkerhet, grunnet problemer med å måle effekt og mulighet for gjennomføring. Stortingsmeldingen Norsk klimapolitikk beskriver en ambisiøs politikk som nasjonalt skal regulere utslipp, bevare skog, forbedre transportsektoren og bidra til innovasjon og teknologi (Meld. St. 21: 8). Men politikken skal også være økonomisk gjennomførbar. Vi har observert en rekke ulike stemmer med ulike synspunkter som skal tas i betraktning, en situasjon som har resultert i en rekke doble eller blandete budskap, som i sin tur kan lede til uklarhet om hvilken politikk regjeringen fører. Vi fortsetter i det følgende med en lignende analyse av stortingsmeldingen om Nordområdene.

\subsection{Stortingsmelding nr. 7 (2011-2012) Nordområdene. Visjon og virkemidler}

\section{Narrativ analyse:}

I Stortingsmelding nr. 7 (heretter Meld. St. 7; Nordområdemeldingen) er Initialsituasjonen presentert som de endrete relasjonene mellom naboland i nordområdene etter slutten på den kalde krigen (Meld. St. 7: 11). De siste 20 årene karakteriseres av en rask utvikling i nord. Stortingsmeldingen fremhever at Barentshavet har potensial til å bli en viktig europeisk energiregion, særlig fordi det forventes at området inneholder enorme uoppdagete olje- og gassreserver. Det påpekes også at området har potensial for utvikling av fornybar energi som vann-, vind- og bølgeenergi.

Komplikasjonen presenteres som økonomiske, teknologiske, infrastrukturelle og miljømessige problemer med utvikling av det store energipotensialet. På grunn av at regionen er sårbar, sier meldingen at økt aktivitet må skje på en måte som tar hensyn til miljø, klima og urbefolkning. Det pekes på at det er viktig å forberede samarbeid mellom næringsvirksomheter og andre interesser (Meld. St. 7: 13-14). Utvikling av petroleumsindustrien i denne regionen skal veies mot andre industrier og interesser innenfor et rammeverk for økonomisk basert styring. Petroleumsutvinning hevdes å kunne bli viktig 
for å styrke Europas energisikkerhet og bidra til verdens energiforsyning, samtidig med at den kan danne et godt grunnlag for industri- og serviceutvikling i Arktis-områdene. Dette er viktig for økonomisk vekst og internasjonale relasjoner. Imidlertid er avstand, markedsforhold, behov for infrastruktur og hensynet til miljø og sikkerhet sentrale utfordringer. Klimaendringer blir slik presentert som én av flere nøkkelfaktorer som vil ha innflytelse på forvaltningen av Nordområdene (Meld. St. 7: 11).

Et hendelsesforløp er i hovedsak presentert fra slutten av den kalde krigen til i dag. Før 1990 hadde sikkerhetsspørsmål høyeste prioritet. En ny fase utviklet seg fra 1990 til 2010: Nordområdenes rolle forandret seg da det oppstod nye spørsmål om blant annet diplomati, miljø, olje og gass (Meld. St. 7: 11-13).

Som reaksjon på denne utviklingen understreker stortingsmeldingen både Norges og Russlands ansvar for regulering av deres respektive kontinentalsokler i Barentshavet. Regjeringen ønsker å bidra til regionens energipotensial ved å fremme et nærere samarbeid mellom myndighetene i de to landene og mellom industri, tjenester og forskning (Meld. St. 7: 14).

Finalsituasjonen er beskrevet i form av nåværende og fremtidige perspektiver på perioden 2011-2030. Klimaendringer, økt tilgang til naturressurser og økt menneskelig aktivitet signaliserer at Arktis vil bli et nytt geopolitisk sentrum. Regjeringens overordnete målsetting er å dra fordel av de mulighetene regionen gir, og samtidig opprettholde en bærekraftig politikk for miljø (Meld. St. 7: 18). Det er et klart mål å legge bedre til rette for mer verdiskaping (Meld. St. 7: 13), og det gjennomgående temaet er hvordan man kan frigjøre energipotensialet på en mest mulig kostnadseffektiv og miljøvennlig måte:

(16) Regjeringen vil legge til rette for en forsvarlig utnyttelse av petroleumsressursene i nord.

(s. 25)

Når Nordområdemeldingen tolkes narrativt, ser vi at den anlegger et bredere perspektiv enn Klimameldingen. Det pekes tidlig i teksten på mange ulike politiske temaer i tillegg til klimaendringene, som internasjonale relasjoner, naturressurser, internasjonal rett og internasjonalt samarbeid. Når det gjelder aktørene eller rollene, presenteres regjeringen, eller snarere Norge, som helten. Det er illustrert i det følgende:

(17) Regjeringen vil at Norge skal være den fremste forvalter av miljøet og naturressursene i nordområdene. (s. 21)

Når det gjelder skurker og ofre, er ikke disse rollene klart tildelt i Nordområde-fortellingen, selv om det i teksten skimtes en underliggende «trussel» fra andre land:

(18) Antakelsen av at en stor del av verdens uoppdagede petroleumsressurser befinner seg i arktiske områder, er en viktig grunn til den økende interessen for Arktis. (s. 12) 
Offerrollen er på sin side i hovedsak knyttet til urbefolkninger. Det er en prioritet at de skal beskyttes, og at de skal delta i samarbeidsorganer som det Arktiske råd (Meld. St. 7: 17, 27). Det overordnete fokus i denne meldingen er imidlertid ikke ofrene, men heller «seierherrene». Det er antydet at den forespeilte industrielle og økonomiske utviklingen i Nordområdene vil være gunstig for lokalsamfunnene, for Norge i sin helhet, for Europa og for hele verden (Meld. St. 7: 12-14):

(19) Regjeringen mener utviklingen i nordområdene har et stort potensial for å bidra til å styrke det langsiktige grunnlaget for sysselsetting og verdiskaping, [...]. (s. 13)

(20) Petroleumsleveranser fra denne regionen vil kunne styrke europeisk energisikkerhet og kunne gi viktige bidrag til verdens energiforsyning (s. 14)

\section{Politisk kontekst:}

Meldingen fremhever at Nordområdene er Norges viktigste strategiske prioritering i utenrikspolitikken. Norge ønsker derfor også i kommende år å bli anerkjent som en aktør med forutsigbare suverenitetskrav og som initiativtaker til åpent samarbeid med andre land (Meld. St. 7: 18). I tillegg til den vekten som legges på det strategiske, er særlig to utfordringer understreket. Den første dreier seg om klimaendringenes globale omfang og viktigheten av å redusere klimagassutslipp, den andre gjelder konsekvensene av klimaendringene. Når det blir varmere i de arktiske områdene, vil sjøisen få en mindre utstrekning, noe som gir muligheter for ny økonomisk aktivitet som skipsfart og olje- og gassutvinning. Men på grunn av områdets sårbarhet kreves det en balanse mellom nye aktiviteter og hensyn til miljø og urbefolkningens levemåte (Meld. St. 7: 78).

Diskusjonen om klimaendringene skiller seg fra fremstilingen i Klimameldingen både når det gjelder kontekstuelle faktorer, og $\mathrm{i}$ fremtidsperspektiver. I Nordområdemeldingen legges det ikke bare vekt på problemene, men desto mer på de mulighetene fremtidige klimaendringer kan skape. Dette kan forklare den betydelige forskjellen mellom de to meldingene når det gjelder å legge vekt på usikkerhet omkring klima. Ordene «usikker(t)»og «usikkerhet» forekommer 57 ganger i Klimameldingen, men bare 5 i Nordområdemeldingen. Den diskursive analysen av den sistnevnte avdekker også en svært annerledes fremstilling av Nordområdene, hvor vekten er lagt på vinnere fremfor tapere og på muligheter fremfor negative konsekvenser.

\section{Polyfonisk analyse:}

Nordområdemeldingen er videre forskjellig fra Klimameldingen når det gjelder involverte aktører og stemmer, med hovedsakelig politiske og ikke vitenskapelige referanser. Den beskjedne rollen som er gitt til FN og FN-organer (som IPCC), er verdt å merke seg. Samtidig er det naturlig at Arktisk råd får en viktig plass i en melding om Nordområdene. Når vi ser på referanser til disse organisasjonene, får vi følgende resultat: 


\begin{tabular}{|l|l|l|}
\hline Referanser til: & FN & Arktisk råd \\
\hline $\begin{array}{l}\text { Meld. St. 21 } \\
\text { Klimameldingen }\end{array}$ & 150 & 15 \\
\hline $\begin{array}{l}\text { Meld. St. 7 } \\
\text { Nordområdemeldingen }\end{array}$ & 24 & 106 \\
\hline
\end{tabular}

FNs konvensjon om havrett er imidlertid fremstilt som en viktig stemme i forvaltningen av Nordområdene:

(21) Havretten gir Norge råderett over betydelige ressurser. Men det betyr også at Norge har et stort ansvar for å forvalte disse områdene på en god måte. (Meld. St. 7: 13)

Her ser vi at konnektoren men og adverbet også indikerer at to perspektiver er involvert. Slik utsagnet er konstruert, blir innholdet i første setning en betingelse for innholdet i setningen innledet med men. Med råderett over ressursene følger ansvar, og det er den siste setningen som er presentert som viktigst. Det er ikke angitt eksplisitt hvilken myndighet som bestemmer hva som er «en god måte», men henvisningen til havrett antyder en ekstern innblanding. Slik legges også en plikt til god forvaltning på eksterne aktører. I det følgende utdraget er det imidlertid klart at det er den norske regjerings stemme som kommer til uttrykk:

(22) Det er et overordnet mål å legge til rette for økt verdiskaping i nordområdene. (s. 13)

Her følger en annen målsetting:

(23) Samtidig som det er et overordnet mål å få til raske reduksjoner i de globale utslippene av klimagasser, vil behovet for fossilt brensel fortsatt være til stede langt inn i dette århundret. Det antas å være betydelige ressurser i nordområdene. (s. 32)

Gjennom den adverbielle innledningen «Samtidig som det er ...» uttrykkes en presupponert enighet om å redusere utslipp. Dette presenteres parallelt med en påstand om behov for fossilt brensel og en antakelse om at det finnes slike ressurser i nordområdene, men uten dyptgående betraktninger omkring konsekvensene av å skulle forfølge disse målsettingene samtidig.

Regjeringen legger opp til å innfri en rekke ønsker som kan ha sin opprinnelse i ulike stemmer i den aktuelle samfunnsdebatten:

(24) Regjeringen vil ta vare på miljøet i nordområdene og legge til rette for verdiskaping og menneskelig aktivitet samtidig som miljøverdiene og naturmangfoldet opprettholdes. (s. 91)

Her forenes regjeringens ambisjon om å integrere den generelle målsettingen om bevaring av miljø og naturmangfold med det sterke ønsket om økt verdiskapning. Slike «flerstemmige» 
utsagn er frekvente i Nordområdemeldingen De er ofte innledet med «samtidig», som ikke bare markerer samtidighet, men også en kontrast mellom to synspunkter.

På grunn av sårbarheten i Nordområdene legger man også vekt på varsomhet:

(25) Regjeringen er derfor opptatt av å ha en kunnskapsbasert tilnærming der miljøkonsekvensene er grundig vurdert før beslutninger om ny aktivitet fattes, og der det er åpenhet om utfordringer og motsetninger mellom ulike interesser og hensyn. (s. 94)

Regjeringen uttrykker en forpliktelse til å sette miljømessige hensyn foran økonomiske, men uten å presentere en måte å oppnå den ønskete balansen på. Det kan synes som den gjennom de flerstemmige utsagnene unngår å ta tak i problemenes iboende konflikter.

I tillegg til ekspansjon av petroleumsvirksomhet og skipsfart ønsker regjeringen å kartlegge mineralressurser og åpne opp for ny gruveindustri, men den ser også problemer:

(26) Utvinning av metaller og mineraler kan medføre store miljøutfordringer, når det gjelder både naturinngrep, håndtering av restavfall og forurensing. (s. 124)

(27) Etablering av ny gruvevirksomhet og ny infrastruktur knyttet til transport, energi og industri vil kunne berøre viktige naturverdier og gjenværende inngrepsfrie naturområder. (s. 124)

De epistemiske «kan» (26) og «kunne» (27) uttrykker her mulige negative konsekvenser.

Oppsummerende kan vi si at måten trusselbilder konstrueres på, er forskjellig i de to meldingene. I Klimameldingen fremstilles klimaendringene som en generell trussel mot verden og menneskeheten og utgjør slik et klart insitament til relevant handling. I Nordområdemeldingen er klimaendringene en trussel mot ny økonomisk virksomhet på grunn av regionens sårbarhet, men først og fremst synes klimaendringene å representere muligheter som åpner opp for den samme økonomiske virksomheten.

\section{Avslutning}

Analysen av de to stortingsmeldingene om klimaendringer har vist at det eksisterer (minst) to konkurrerende «fortellinger» i norsk politikk. Dette ble først vist gjennom en narrativ analyse av dokumentene.

Klimameldingen presenterer en «fortelling» med en intrige som handler om å takle klimaendringene, hvor regjeringen gir seg selv en klar helterolle. Samtidig betraktes rike industrialiserte land som ansvarlige for det endrete klimaet og får slik en slags «skurkerolle», mens utviklingsland med små klimagassutslipp og stor fattigdom blir ofre. Nordområdemeldingen presenterer derimot en «fortelling» hvor klimaendringer representerer både trusler og muligheter, men med en særlig vekt på muligheter for verdiskaping og ny økonomisk virksomhet, som petroleumsutvinning. Som forventet i den type politisk dokument en stor- 
tingsmelding er, gir regjeringen også her seg selv helterollen, mens det ikke tildeles åpenbare skurke- eller offerroller.

Vi mener å ha fått bekreftet hypotesen som ble presentert i introduksjonen, om doble budskap i norsk klimapolitikk som skyldes konkurrerende interesser: Klimaendringene skal takles, og petroleumsindustrien skal videreutvikles på samme tid. Den narrative og kontekstuelle analysen har vist at samme regjering presenterer to forskjellige «fortellinger» $\mathrm{i}$ de to stortingsmeldingene. Polyfonianalysen har avdekket flere doble budskap i hvert av de to dokumentene; ulike og til dels motstridende stemmer er integrert i diskursen. Dette tyder på at det ikke bare er flere stemmer til stede i de aktuelle stortingsmeldingene, men at ulike stemmer også kan velges bort i enkelte sammenhenger. Vi vil også hevde at den narrative analysen, gjennom de forskjellige komponenter og roller som kan identifiseres, bidrar til en bedre forståelse av diskursen og slik tilfører viktig innsikt i kunnskapsbasen om klimafenomenet. Videre har polyfonianalysen vist både eksplisitte og implisitte stemmer og dermed bidratt til en bedre forståelse av de ulike perspektivene som eksisterer i klimadebatten. Vi mener et viktig funn er de forskjellige fremstillingene av selve klimautfordringene $\mathrm{i}$ de to meldingene. Klimameldingen tar utgangspunkt $\mathrm{i}$ et vitenskapelig basert perspektiv og fremsetter tydelig at utslippskutt er regjeringens overordnete prioritering. Nordområdemeldingen fremstiller derimot klimaendringer som en utfordring som må tas hensyn til, men legger vekt på at de fører til endrete rammebetingelser for Nordområdene som kan fremme ny industri og gi muligheter for økonomisk vekst.

Det ligger utenfor rammen for denne artikkelen å vurdere gjennomføring av foreslåtte tiltak og politikk i de to meldingene. Men det er grunn til å spørre hvilken effekt slike doble budskap har på folks holdninger til klimaspørsmålet. Kan det føre til mer likegyldighet eller oppgitthet i møte med et allerede svært komplekst fenomen? I et intervju om klima i Bergens Tidende 1. juni 2013 sa daværende statsminister Jens Stoltenberg følgende: «Målet er ikke å holde karbonet i bakken. Målet er å redusere utslippene til atmosfæren.» Dette utsagnet fanger dobbelheten i norsk klima- og energipolitikk: Norge er en stor olje- og gassprodusent og samtidig et land som har rykte for å være, eller kanskje heller et ønske om å være, internasjonalt ledende i miljø- og klimaspørsmål. I oktober 2013 fikk landet en ny regjering, og det gjenstår å se om deres klimapolitikk vil ta en annerledes retning. I den siste tiden har representanter for regjeringen beskrevet «Norge [som] oljeprodusenten som bruker oljeinntektene på klimatiltak [...]. Det er et paradoks som vi egentlig bør være stolte av». (Kronikk i VG, 26.08.14, av Tine Sundtoft, klima- og miljøminister (H), og Tord Lien, olje- og energiminister (FrP)). Og det kan se ut som norsk naturgass er i ferd med å bli den nye «helten» i norsk klimapolitikk, som «renere» enn olje og som brobyggeren over til et samfunn med lavere karbonutslipp.

Hvordan den norske politikken enn blir, er Norge preget av en dualitet: den rike og vellykkete produsenten av fossilt brennstoff og samtidig landet som søker internasjonal anerkjennelse for sin klima- og miljøpolitikk. 
Forskningen som er presentert i denne artikkelen er utført innenfor LINGCLIM-prosjektet (ww.uib.no/en/project/lingclim) finansiert av

Norges forskningsråd gjennom SAMKUL-programmet.

Forfatterne vil takke to anonyme fagfeller og redaktøren for konstruktive og grundige tilbakemeldinger på et tidligere utkast av artikkelen og Torodd Kinn for språklig gjennomgang av manuskriptet.

*Forfatter Tonje Espeland var ansatt som vitenskapelig assistent ved Institutt for sammenliknende politikk, Universitetet i Bergen, da artikkelen ble skrevet.

\section{Referanseliste}

Adam, J.-M. (1985). Le texte narratif. Paris: Nathan.

Adam, J.-M. (2008). La linguistique textuelle. Introduction à l'analyse textuelle des discours. Paris: A. Colin.

Andresen, S., Kolshus, H. H. \& Torvanger,A. (2002). The feasibility of ambitious climate agreements. CICERO Working Paper 2002:03, Oslo: Cicero.

Boykoff, M. (2011). Who speaks for the climate? Making sense of media reporting on climate change. Cambridge: Cambridge University Press.

Carvalho, A. (2005). Representing the politics of the greenhouse effect: Discursive strategies in the British media. Critical Discourse Studies 2(1), 1-29.

Dahl, T. \& Fløttum, K. (2014). A linguistic framework for studying voices and positions in the climate debate. Text \& Talk, 34(4), $401-420$.

Eide, E., Kunelius, R., \& Kumpu, V. (Red.). 2010. Global climate, local journalisms. A transnational study of how media make sense of climate summits. Bochum \& Freiburg: Projektverlag.

Entman, R. M. (1993). Framing: Toward a clarification of a fractured paradigm. Journal of Communication $57(1), 51-58$.

Fløttum,K. (2005). The self and the others - polyphonic visibility in research articles. International Journal of Applied Linguistics 15, 29-44.

Fløttum,K. (2013). Narratives in reports about climate change. I: Gotti, M. \& and Guinda, C.S. (Red.). Narratives in Academic and Professional Genres. Bern: Peter Lang, 277-292.

Fløttum, K. \& Dahl, T. (2011). Climate change discourse: Scientific claims in a policy Setting. Fachsprache 3-4, 205-219.

Fløttum, K. \& Dahl, T. (2012). Different contexts, different "stories"? A linguistic comparison of two development reports on climate change. Language and Communication 32, 14-23.

Fløttum,K., Dahl, T. \& Kinn, T. (2006). Academic Voices - across languages and disciplines. Amsterdam: Benjamins.

Fløttum,K. \& Gjerstad, Ø. (2013a). Arguing for climate policy through the linguistic construction of Narratives and voices: the case of the South-African green paper "National Climate Change Response". Climatic Change 118 (2), 417-430. DOI: 10.1007/s10584-012-0654-7.

Fløttum,K. \& Gjerstad, Ø. (2013b). The role of social justice and poverty in South Africa's national climate change response White Paper. South African Journal on Human Rights, 1, 61-90.

Fløttum,K. \& Stenvoll, D. (2009). Blair speeches in a polyphonic perspective: NOTs and BUTs in visions on Europe. Journal of Language and Politics 8 (2), 269-286

Giddens, A. (2009). The politics of climate change. Cambridge: Polity.

Grundmann, R. (2007). Climate change and knowledge politics. Environmental Politics 16 (3), 414-432.

Hulme, M. (2009). Why we disagree about climate change. Cambridge: Cambridge University Press.

Jones, M. D. \& McBeth, M.K. (2010). A narrative policy framework: Clear enough to be wrong? The Policy Studies Journal 38 (2), 329-353.

Jones, M. D. (2013). Cultural Characters and Climate Change: How Heroes Shape our Perceptions of Climate Science. Social Science Quarterly 93 (3), 713-731.

Koteyko, N. (2012). Managing carbon emissions: A discursive presentation of 'market-driven sustainability' in the British media. Language and Communication 32, 24-35.

Koteyko, N., Thelwall, M. \& Nerlich, B. (2010). From carbon markets to carbon morality: Creative compounds as framing devices in online discourses on climate change mitigation. Science Communication 32(1), $25-54$.

Krosnick, J. A., Holbrook, A. L., Lowe, L. \& Visser, P.S. (2006). The origins and consequences of democratic citizens' policy agendas: A study of popular concern about global warming. Climatic Change 77, 7-43.

Krzyżanowski, M. (2013). Policy, policy communication and discursive shifts. Analyzing EU policy discourses on climate change. I: Cap, P. \& Okulska, U. (Red.). Analyzing Genres in Political Communication. Amsterdam: Benjamins, 101-133. 
Kurz, T., Augoustinos, M. \& Crabb, S. (2010). Contesting the 'national interest' and maintaining 'our lifestyle': A discursive analysis of political rhetoric around climate change. British Journal of Social Psychology 49, 601-625.

Leiserowitz, A. (2006). Climate change risk perception and policy preferences: the role of affect, imagery, and values. Climatic Change 77, 45-72.

Meld. St. 7 - Melding til Stortinget 7 (2011-2012) Nordområdene. Visjon og virkemidler. (Nordområdemeldingen).

Meld. St. 21 - Melding til Stortinget 21 (2011-2012) Norsk klimapolitikk. (Klimameldinegn).

Nerlich, B., Koteyko, N. \& Brown, B. (2010). Theory and language of climate change communication. Wiley Interdisciplinary Reviews: Climate Change 1(1), 97-110.

Nisbet, M. C. (2009). Communicating climate change: Why frames matter for public engagement. Environment. Science and Policy for Sustainable Development, http://www.environmentmagazine.org/Archives/Back\%20Issues/March-April\%202009/Nisbet-full.html.

Norgaard, K. M. (2006). "We don't really want to know": Environmental justice and socially organized denial of global warming in Norway. Organization \& Environment 19(3), 347-370.

Nølke, H., Fløttum, K. \& Norén, C. (2004). ScaPoLine. La théorie scandinave de la polyphonie linguistique. Paris: Kimé.

Painter, J. (2011). Poles apart: the international reporting of climate scepticism. Oxford: Reuters Institute for the Study of Journalism, University of Oxford.

Ryghaug, M., Sørensen, K. H. \& Næss, R. (2011). Making sense of global warming: Norwegians appropriating knowledge of anthropogenic climate change. Public Understanding of Science 20, 778-795.

Trumbo, C. (1996). Constructing climate change: Claims and frames in US news coverage of an environmental issue. Public Understanding of Science 5, 269-283.

Weber, E. (2006). Experience-based and description-based perceptions of long-term risk: Why global warming does not scare us (yet). Climatic Change 77(1-2), 103-120.

Wodak, R. (2013). Analyzing meetings in political and business contexts. Different genres - similar strategies? I: Cap, P. \& Okulska, U. (Red.). Analyzing Genres in Political Communication. Amsterdam: Benjamins, $187-221$. 